\title{
Effect of Trichoderma Fortified Compost on Disease Suppression, Growth and Yield of Chickpea
}

\author{
Prosenjit Talukdar ${ }^{1}$, Mst. Mahfuja Siddiqa ${ }^{2}$, Md. Mahidul Islam Masum $^{1 *}$, \\ A.B.M. Habibullah ${ }^{3}$, Md. Khurshed Alam Bhuiyan ${ }^{1}$ \\ ${ }^{1}$ Department of Plant Pathology, Bangabandhu Sheikh Mujibur Rahman Agricultural University, Gazipur- \\ 1706, Bangladesh \\ ${ }^{2}$ Department of Botany, Jagannath University, Dhaka 1100, Bangladesh \\ ${ }^{3}$ Department of Economics, Asian University of Bangladesh, Dhaka 1230, Bangladesh \\ *Corresponding author: \\ Email: masum@bsmrau.edu.bd
}

\begin{abstract}
Trichoderma species are commonly used as effective biological control agents against phytopathogens especially the soil-borne fungi while some isolates are able to ameliorate plant growth. In the present study, Trichoderma fortified compost with different substrates were evaluated to reduce the preemergence and post-emergence seedling mortality, diseases of stem and root of chickpea caused by several soil-borne fungal pathogens, including Fusarium oxysporum, Rhizoctonia solani and Sclerotium rolfsii at different growth stages in the field under natural epiphytotic conditions. Among the twenty isolates of T. harzianum, Co-7 showed the most effective antagonist against the test pathogens in dual culture method. In field experiment, subsequently it was used for inoculum preparation with colonized wheat grain and mixed with well-matured decomposed composting materials like, saw dust, cow dung, tea waste, water hyacinth and poultry manure. Trichoderma fortified compost with poultry manure was found significantly effective in reducing preemergence and post emergence seedling mortality, disease incidence and disease severity of chickpea in the field. Interestingly, all the treatments significantly increased but Trichoderma fortified compost with poultry manure was the best to boost seed yield and quality.
\end{abstract}

Keywords - biocontrol, Cicer arietinum, seedling diseases, soil-borne fungi, yield.

\section{INTRODUCTION}

Chickpea (Cicer arietinum) is the world's fourth most important pulse crop after soybeans, beans and peas (FAO, 2012). Diseases are one of the main constrains for the low production of this crop (Godhani et al., 2010). Chickpea crop is attacked by wide range of pathogens including fungi, viruses, bacteria, nematodes and mycoplasma (Nene and Sheila, 1996). Some of the serious pathogens usually known as soil-borne pathogens in order of their importance including Fusarium oxysporum f. sp. ciceri, Rhizoctonia solani, and Sclerotium rolfsii are the most devastating in both seedling and mature stage. Under favourable conditions, outbreaks of these pathogens it cause yield and quality deterioration or, even there is a total crop failure and result in a huge economic losses.

Many attempts have been made to control $F$. oxysporum f. sp. ciceri, $R$. solani, and $S$. rolfsii including cultural or chemical methods (Jaacov, 2000) but neither cultural nor chemical measures alone were found to be effective against these pathogens. Controlling of these soil-borne diseases with fungicides is uneconomical and difficult to achieve because of the soil and seed-borne nature of the pathogen (Ahmad et al., 2010). Moreover, the application of fungicides causes groundwater pollution, killing of non-target beneficial flora and evolving fungicidal resistance variants of the pathogen. The antagonistic Trichoderma, a cosmopolitan soil and compost-borne saprophytic fungus can be used to suppress soil-borne pathogens that cause diseases such as damping-off, root rots, stem rots, and wilting in many vegetables. In addition to its effect as a natural enemy of plant pathogens, Trichoderma has also a positive impact on plant growth as it produces different kinds of secondary metabolites which are important for plant growth regulation (Vinale et al., 2009) and improves the soil fertility by acting as decomposer. Composts or compost extracts used as an organic fertilizer have beneficial effects on plant growth and considered as a valuable soil amendment (Gharib et al., 2008). Recently Trichoderma fortified compost have been used in many countries and appeared very effective in controlling different soil-borne 
pathogen as well as increasing growth and yield of many crops (Kaewchai et al., 2009, Rahman, 2013). However, scanty published reports on disease suppression and improvement of growth and yield of this pulse crop are available in Bangladesh utilizing Trichoderma fortified compost. Therefore, this study was undertaken to select the most effective isolates of Trichoderma species against different soil-borne fungi of chickpea identified under lab condition and to assess the potential of Trichodermafortified compost in controlling fungal diseases and enhancing growth and yield of chickpea in the field.

\section{MATERIALS AND METHODS}

2.1 Collection, isolation and preservation of Trichoderma spp. isolates

A total of 20 isolates of Trichoderma spp. were collected from soils of different crop fields of Chandina Upazilla of Comilla districts of Bangladesh. Soils samples were collected from rhizophere soil of carrot, radish, tomato, potato, brinjal and chilli. Fungi were isolated from individual samples following the soil dilution plate technique (Mian, I995). Briefly, a total of $10 \mathrm{gm}$ of soil from a sample was mixed with $90 \mathrm{ml}$ of sterilized water in a sterile conical flask while suspension was in motion. The initial soil sample was diluted through serial dilutions in order to achieve a small number of colonies on each plate. Then $5 \mathrm{ml}$ of each dilution was incorporated into a plate with PDA (potato, $250 \mathrm{~g}$; dextrose, $20 \mathrm{~g}$; agar, $20 \mathrm{~g}$; distilled water upto 1L) amended by $100 \mathrm{ppm}$ streptomycin sulfate. The Petri dishes were incubated for $3-5$ days at room temperature $\left(25 \pm 2^{\circ} \mathrm{C}\right)$. Fungus was purified on PDA following hyphal tip culture technique (Tuite, 1969). A total of 20 fungal isolates were identified as $T$. harzianum on the basis of growth, colony and morphological characters following the standard key (Barnett and Hunter, 1998). The other isolated fungi were discarded.

\subsection{Testing the antagonistic activity of $T$. harzianum} isolates in vitro

Twenty isolates of $T$. harzianum were tested against $F$. oxysporum, $R$. solani and $S$. rolfsii on potato dextrose agar (PDA) medium $\mathrm{f}$ dual culture technique by placing 5 $\mathrm{mm}$ diameter young mycelium disc of pathogen at one end and that of the biocontrol agent at the other end of a 9 cm diameter Petri dish (Dhingra and Sinclair, 1985). The selected virulent isolates of test pathogens were collected from the stock culture of the laboratory of the Department of Plant Pathology, BSMRAU. All plates were incubated in the dark at $25^{\circ} \mathrm{C}$ until the mycelium of $F$. oxysporum, $R$. solani and $S$. rolfsii covered the whole area of the control plate. Inhibition percentage of the radial growth of $F$. oxysporum, $R$. solani and $S$. rolfsii were calculated following the formula as suggested by Sundar et al. (1995):

$\%$ Inhibition of growth $=\frac{X-Y}{X} \times 100 \quad($ equation 1$)$

Where, $X=$ mycelial growth of pathogen in absence of T. harzianum (control), $\mathrm{Y}=$ mycelial growth of pathogen in presence of $T$. harzianum).

\subsection{Preparation of Trichoderma fortified compost with different substrates}

Before setting the experiment in the field, a total of five compost pits $(1.0 \mathrm{~m} \times 1.0 \mathrm{~m} \times 1.5 \mathrm{~m})$ were prepared separately where each compost pit contained $40 \mathrm{~kg}$ each of saw dust, tea waste, poultry manure, water hyacinth and cow dung. After 45 days of decomposition wheat grain colonized Trichoderma inoculum @2.5 kg was mixed in each compost pit. Then it was left for 90 days for decomposition and degradation following the procedure of the preparation of standard quality compost as described by James (2008). On the basis of screening test against the studied virulent isolates of $F$. oxysporum, $R$. solani and $S$. rolfsii, the highly antagonist isolate of $T$. harzianum $\mathrm{Co}-7$ was selected for the field experiment

2.4 Application Trichoderma fortified compost with different substrates for controlling major diseases of chickpea in field condition

A field experiment was conducted to evaluate the most effective composting substrate mixed with $T$. harzianum isolate Co-7 for controlling major soil borne diseases of chickpea as well as its impact on growth promotion and increasing the yield of chickpea. Prepared Trichoderma fortified compost @ $5 \mathrm{~kg} \operatorname{plot}^{-1}\left(8.33 \mathrm{t}\right.$ ha $\left.{ }^{-1}\right)$ with individual substrates as described earlier were used in the field as treatments. Seeds of chickpea (Cicer arietanum) variety BARI Chola-5 collected from Bangladesh Agricultural Research Institute, Joydebpur, Gazipur were grown for this purpose in a non-sterile field soil. This experiment included following seven treatments:

- $\mathrm{T}_{1}=$ sowing of seeds only in field soil (Control 1)

- $\mathrm{T}_{2}=$ Wheat bran colonized Trichoderma without compost (Control 2)

- $\mathrm{T}_{3}=$ Colonized Trichoderma with saw dust

- $\mathrm{T}_{4}=$ Colonized Trichoderma with cow dung

- $\mathrm{T}_{5}=$ Colonized Trichoderma with tea waste

- $\mathrm{T}_{6}=$ Colonized Trichoderma with water hyacinth

- $\mathrm{T}_{7}=$ Colonized Trichoderma with poultry manure

\subsection{Monitoring of disease development}

Chickpea plants were observed regularly after sowing to record the incidence of pre-emergence and postemergence seedling mortality, infection both on plant organs and pods at different growth stages. The causal agents of the recorded diseases were identified on 
isolation of the pathogen from the infected roots, stems and pod. The disease incidence was recorded continuously at 3 days interval from transplanting to final harvest. Observations were made by selecting five plants randomly from each plot. Disease severity of wilt, wet root rot and collar rot caused by $F$. oxysporum, $R$. solani and $S$. rolfsii, respectively was rated as 0-4 scale in which $0=$ no symptoms, $1=1-25 \%, 2=26-50 \%, 3=51-75 \%$ and $4=76-100 \%$ of chickpea organ covered with lesions (Morid et al., 2012). Diseases of the crop were expressed as percentage using the following formulae:

- Disease incidence

$=\frac{\text { Number of infected plants }}{\text { Total number of plant observed }} \times 100$ (Equation 2)

- Percent disease index (PDI) =

$\frac{\text { Summation of all rating }}{\text { Number of plant observed } \times \text { Maximum rating }} \quad$ x $\quad 100$

(Equation 3)

2.6 Observation of growth promoting factors at maturity and yield

Growth promoting factors including plant height, no. of branches plant ${ }^{-1}$ and numbers of pods plant ${ }^{-1}$ were recorded randomly five plants from each replicated plots of all the treatments attain after certain maturity. Pods plant $^{-1}$ was harvested and the total dry weight of seed was also measured.

\subsection{Design of experiment and data analyses}

The field experiment was laid out in the Randomized Complete Block Design (RCBD) with four replications. Data recorded on various diseases and yield components were analyzed statistically using the STATISTIX 10 computer program after proper transformation whenever necessary and the means were compared following DMRT.

\section{RESULTS}

3.1 Screening of $T$. harzianum isolates against $F$. oxysporum f. sp. ciceri, $R$. solani, and $S$. rolfsii

All the 20 isolates of $T$. harzianum showed more than $60 \%$ inhibition of radial growth of the tested pathogens as compared to untreated control except the isolate Co-6 where the growth inhibition against $R$. solani was $58.8 \%$. Among the screened isolates of $T$. harzianum only four isolates namely Co-5, Co-7, Co-12 and Co-20 showed above $70 \%$ growth inhibition against all the tested pathogens (Table 1). The same isolate of T. harzianum had highly varied antagonistic ability and it ranged from 60 to $80 \%$ depending on the test pathogen. However, the tested isolates Co-7 showed the highest inhibition of the radial growth among all the tested pathogens (Table 1 and Fig. 1).

3.2 Assessment of Trichoderma fortified composts applied in the chickpea field in controlling soil-borne diseases

\subsubsection{Effect on seedling mortality}

Immediately after sowing of chickpea seed, preemergence and post-emergence seedling mortality caused by $F$. oxysporum, $R$. solani and $S$. rolfsii were recorded up to five weeks of the plant growth. The highest reduction of total seedling mortality over control $(69.31 \%)$ was recorded in plants receiving a combined treatment with the Trichoderma fortified compost mixed with poultry manure as substrate $\left(\mathrm{T}_{7}\right)$. However, the similar result with $T_{7}$ was also observed in treatment $T_{4}$ and $T_{5}$ where the field soil received cow dung and tea waste with $T$. harzianum isolate, respectively (Table 2). Other treatments $\left(\mathrm{T}_{6}\right.$ and $\left.\mathrm{T}_{3}\right)$ showed statistically similar effect on seedling mortality in comparison to the untreated control where only chemical fertilizers were mixed without Trichoderma fortified compost.

\subsubsection{Effect on disease development}

All the Trichoderma fortified composts reduced superiorly diseases of chickpea in comparison to untreated control. Among the diseases, wet root rot caused by $R$. solani was the most prevalent followed by collar rot caused by Sclerotium rolfsii and Fusarium wilt caused by $F$. oxysporum (Table 3 ). Significantly the highest reductions of the marked three diseases over control were achieved with Trichoderma fortified compost with poultry manure $\left(\mathrm{T}_{7}\right)$ followed by the treatment containing mixtures of Trichoderma and cow dung (Table 3). Additionally, the highest reduction of PDI over control was also observed in the treatment $\mathrm{T}_{7}(64.9 \%$ of $F$. oxysporum, $67.8 \%$ of $S$. rolfsii \& $65.7 \%$ of $R$. solani) in case of all the diseases but those of treatments $T_{4}$ and $T_{5}$ were numerically almost similar followed by $T_{6}$ in case of collar rot and wilt (Table 4). However, in case of the reduction of PDI caused $R$. solani treatment $\mathrm{T}_{7}$ was highest $(65.7 \%)$ but $\mathrm{T}_{4}$ and $\mathrm{T}_{5}$ were almost numerically identical to $\mathrm{T}_{7}$.

3.3 Performance of Trichoderma fortified compost on growth promoting components and yield of chickpea in the field

Trichoderma fortified compost increased the growth promoting components including the number of branch plant $^{-1}$ and plant height compared to those of untreated control $\left(T_{1}\right)$. In case of pods plant ${ }^{-1}$ treatments $T_{2}, T_{3}, T_{5}$, $\mathrm{T}_{6}$ were statistically identical but significantly lower to those of $\mathrm{T}_{7}$ treatment where Trichoderma were mixed with poultry manure (Table 5). The treatments containing mixtures of colonized Trichoderma with cow dung and Trichoderma with poultry refuses were found statistically similar in increasing all growth promoting characters. Similarly significantly the highest seed yield $\left(1.54 \mathrm{t} \mathrm{ha}^{-1}\right)$ was recorded in the plot with Trichoderma compost using poultry manure $\left(\mathrm{T}_{7}\right)$ followed by treatment $\mathrm{T}_{4}$ using cow dung as compost. On the other hand, identical seed yield 
and seed weight were observed in $\mathrm{T}_{5}$ and $\mathrm{T}_{6}$ treated plot but they were significantly lower than that of $\mathrm{T}_{7}$ in seed yield (Table 5).

\section{DISCUSSION}

Soil-borne pathogens such as $F$. oxysporum f. sp. ciceri, $R$. solani and $S$. rolfsii are primarily known as devastating pathogens to cause seedling diseases in chick pea cultivation. These pathogens are mostly difficult to control as they often reside alive for many years as sclerotia in soil or as mycelia in soil under several environmental conditions and subsequently attack the crops resulting poor yield. Now a-days, Trichoderma is widely considered as a potential cost-effective means against several pathogens attacking vegetables, fruits, field and industrial crops (Tran, 2010). In our study, we got many isolates of Trichoderma harzianum from rhizophere soil of different vegetables in Bangladesh. In vitro assay clearly showed that antagonists $T$. harzianum halted the radial mycelium growth of highly virulent isolate $F$. oxysporum, $R$. solani and $S$. rolfsii, with varying levels of antagonism. Similar antagonistic effect of T. harzianum against these soil-borne pathogens infecting many other crops was also observed by several other investigators (Sundar et al., 1995, Bhuiyan et al., 2007, Nitu et al., 2016). The variation among the different isolates of $T$. harzianum may be come about due to their genetic makeup for the antagonistic activity (Shanmugam et al., 2008, Kumar et al., 2011), production of virulence factor such as metabolites (Shentu et al., 2014), trichodene (Malmierca et al., 2015) etc. Moreover, a variety of extracellular lytic enzymes such as high chitinase and $\beta$-(1,3)-glucanase have been reported to be produced by T.harzianum (Kumar et al., 2012), and there may be relationship between the production of these enzymes and the ability to inhibit the pathogen (Elad et al., 1982, Sivan and Chet, 1989). Results in this study also revealed that the radial mycelial growth of the pathogens was interfered by $T$. harzianum within the contact area or interface zone.

Under field conditions, we have observed seedling mortality caused by $F$. oxysporum, $S$. rolfsii, and $R$. solani. Some reports accounted these soil-borne pathogens causing diseases in different vegetable crops including chick pea (Prashad et al. 2014, Akhter et al., 2015). As these warm-dependent pathogens are mostly common in Bangladesh soil, soil amendments using composted agricultural wastes fortified with biocontrol agents could be acceptable approaches in this regard. A number of investigations have also showed that the organic amendments of soil with various origins were potential biological control agents in suppressing soilborne plant pathogens (Litterick et al. 2004). Result of this study is also consistent with the consequence of a variety of soil amendments (Noble and Coventry 2010, Akter et al., 2016). The highest disease occurrence in the untreated control plot $\left(\mathrm{T}_{1}\right)$ in case of all diseases followed by treatment $\mathrm{T}_{2}$ where wheat bran colonized Trichoderma without compost was used indicated that the soil-borne pathogens were the most prevalent in the natural field condition even without artificial inoculation of the pathogens. Consequently, organic amendments with Trichoderma fortified with poultry manure yielded the lowest disease incidence as well as disease severity in this study. Moreover, crop treated with $T$. harzianum grown better and had higher yields to compare with the one without application. Different mechanisms have been suggested as being responsible for the action of individual bio-agents and composts. Disease suppressive effect of Trichoderma compost might be due to increase in microbial biomass of Trichoderma with the ideal food base compost, it aids in their introduction and establishment into the soil for sustained biocontrol activities of soil micro biota as stated by Hoitink and Boehm (1999). An antagonist parasitizes the pathogens, and poultry manure might be improved soil nutrients status and enhanced the efficacy of antagonist. The superior inhibitory effect of poultry manure is suggested to be related with the release of antifungal compounds from it. Poultry compost contains NH4-N and NO3-N while Brady (1974) claimed that nitrate-nitrogen can be readily taken by plants but where carbon-based organic residue are available, resident soil micro organisms tend to exploit NH4+ more quickly than plants. Considerable evidence has piled up to support the idea that ammonia liberated following application of high nitrogen amendments contributes to kill soil-borne pathogens (Shiau et al., 1999). Additionally, the bio-control activities of $T$. harzianum against $F$. oxysporum f. sp. ciceri, $R$. solani modulate the induced plant resistance and enhance the plant growth (Sivan, 1989, Malik et al, 2005, Saxena et al., 2015). These results support the present findings of controlling soil-borne diseases as well as increasing growth promoting parameters and seed yield of chick pea by Trichoderma fortified composting.

\section{CONCLUSION}

Results from this study showed that poultry manure was appeared to be excellent and promising substrates for the preparation of Trichoderma fortified compost in controlling soil-borne diseases of chickpea. Trichoderma fortified compost with different substrates had also better effect in increasing different growth parameters as well as yield of chickpea than the untreated control where Trichoderma was not mixed. Farmers can adopt ecofriendly control measures of different soil borne diseases 
of vegetables by using Trichoderma fortified compost with the lower cost in comparison to chemical pesticides which is a key to profitable organic farming. Overall, results obtained from this study clearly indicated that Trichoderma fortified compost was the most effective not only control the pathogenic diseases but also achieved directly through storage of compost carbon, and indirectly through enhanced plant growth and biological control which in turn contributes to increased soil carbon levels. However, the experiment should be repeated to standardize the ratio and composition of the compost substrate to prepare the most effective Trichoderma fortified compost.

\section{ACKNOWLEDGEMENTS}

The author has been thankful to Bangabandhu Sheikh Mujibur Rahman Agricultural University (BSMRAU), Bangladesh for providing the Research Assistant Scholarship under the Project on Higher Education Quality Enhancement Project (HEQEP), CP-2075 provided by University Grant Commission during the period of study.

\section{REFERENCES}

[1] Ahmad, M.A., Iqbal, S.M., Ayub, N., Ahmad, Y. and Akram, A. 2010. Identification of resistant sources in chickpea against Fusarium wilt. Pak. J. Bot., 42: 417-426.

[2] Akhter, A., Hage-Ahmed, K., Soja, G. and Steinkellner, S. 2015. Compost and biochar alter mycorrhization, tomato root exudation, and development of Fusarium oxysporum f. sp lycopersici. Front Plant Sci., 6:529

[3] Akter, M., Masum, M.M.I., Bhuiyan, M.K.A. and R. Jannat. 2016. Bio-efficacy of Trichodermafortified compost in controlling onion diseases and improving yield of onion (Allium cepa L.). Int. J. Biosci., 9(1): 225-236.

[4] Barnett, H.L. and Hunter, B.B. 1998. Illustrated genera of imperfect fungi. New York, USA: American Phytopathogycal Society Press, p. 218.

[5] Bhuiyan, M.K.A., Ahmed, I. and Begum, F. 2007. Integrated management of seedling mortality of cauliflower (Brassica oleraceae var. capitata) caused by sclerotium rolfsii. Journal of Agril. Science and Tech., 8 (1\&2):79-86.

[6] Brady, N.C. 1974. The Nature and Property of Soils. 8th Ed. Macmillan Publishing Company, Inc., New York, N.Y

[7] Dhingra, O.D. and Sinclair, J.B. 1995. Basic plant pathology methods. Boca Raton, FL: CRC Press, p. 293.
[8] Elad, Y., Chet, I. and Henis, Y. 1982. Degradation of plant pathogenic fungi by Trichoderma harzianum. Canadian Journal of Microbiology, 28:719-725.

[9] FAO. 2012. FAOSTAT database: agriculture production. Rome: Food and Agriculture Organization of the United Nations.

[10] Gharib, F. A., Moussa, L. A and Massoud, O. 2008. Effect of compost and bio-fertilizers on growth, yield and essential oil of sweet Marjoram (Majorana hortensis) plant. Int. J. Agric. Biol., 10: 381-387.

[11] Godhani, P.H., Patel, R.M., Jani, J.J., Patel, A.J. and Korat, D. M. 2010. Evaluation of two antagonists against wilt disease of chickpea. Karnataka J. of Agric. Sci., 23(5):795-797

[12] Hoitink, H.and Boehm, M. 1999. Biocontrol within the context of soil microbial communities: a substrate-dependent phenomenon. Annual Review of Phytopathology, 37(1):427-446.

[13] James, I. 2008. Effects of compositions on food waste composting. Bioresource Technology, 99 (17): 8068-74.

[14] Kaewchai, S., Soytong, K. and Hyde, K.D. 2009. Mycofungicides and fungal biofertilizers. Fungal Diversity, 38: 25-50.

[15] Kumar, K., Amaresan, N., Bhagat, S., Madhuri, K. and Srivastava, R.C. 2012. Isolation and characterization of Trichoderma spp. for antagonistic activity against root rot and foliar pathogens. Indian Journal of Microbiology, 52(2):137-144.

[16] Kumar, K., Amaresan, N., Bhagat, S., Madhuri, K., Udhayaraj, P. and Srivastava, R.C. 2011. Genetic and physiological relatedness of antagonistic Trichoderma isolates against soil borne plant pathogenic fungi. Archives of Phytopathology and Plant Protection, 44(14):1399-1409.

[17] Litterick, A.M., Harrier, L., Wallace, P., Watson, C.A. and Wood, M. 2004. The role of uncomposted materials, composts, manures, and compost extracts in reducing pest and disease incidence and severity in sustainable temperate agri-cultural and horticultural crop production: A review. Criti-cal Reviews in Plant Sciences, 23:453-479.

[18] Malik, K.A., Hafeez, F.Y., Mirza, M.S., Hameed, S., Rasul, G. and Bilal, R. 2005. Rhizospheric plantmicrobe interactions for sustainable agriculture. In: Wang YP et al. (eds) Biological nitrogen fixation, sustainable agriculture and environment. Springer, Netherlands, pp. 257-260.

[19] Malmierca, M.G., Mccormick, S.P., Cardoza, R.E., Alexander, N.J., Monte, E. and Gutierrez, S. 2015. 
Production of trichodiene by Trichoderma harzianum alters the perception of this biocontrol strain by plants and antagonized fungi. Environmental Microbiololgy, 17(8): 2628-2646.

[20] Mian, I. H. 1995. Methods in plant pathology. IPSA-JICA project publication no 24. Institute of Post Graduate Studies in Agriculture. Gazipur. p.136.

[21] Morid, B., Hajmansoor, S. and Kakvan, N. 2012. Screening of resistance genes to Fusarium root rot and Fusarium wilt diseases in tomato (Lycopersicon esculentum) cultivars using RAPD and CAPs markers. European J. of Experimental Biology., 2 (4): 931-939.

[22] Nene, Y.L. and Sheila, V.K. 1996. ICRISAT. Newsletter, proceeding on international workshop on chickpea, improvement. Feb. March-1996. Pp. 172-180.

[23] Nitu, N. J., Masum, M.M.I., Jannat, R., Bhuiyan, M.K.A. and Sultana, S. 2016. Application of chitosan and Trichoderma against soil-borne pathogens and their effect on yield of tomato (Solanum lycopersicum L.). Int. J. Biosci., 9(1):1024.

[24] Noble, R. and Coventry, E. 2010. Suppression of soil-borne plant diseases with composts: a review. Biocontrol Sci Techn, 15(1):3-20.

[25] Prasad, J., Gaur, V.K. and Mehta, S. 2014. Pathogenicity and Characterization of Rhizoctonia solani Kühn inciting wet root rot in chickpea. The Journal of Rural and Agric Research, 14(1): 12-14.

[26] Rahman, R. 2013. Trichoderma fortified compost in controlling diseases and in increasing yield of tomato. MS thesis, Bangabandhu Sheikh Mujibur Rahman Agricultural University, Salna, Gazipur1706.

[27] Saxena A., Raghuwanshi, R. and Singh, H.B. (2015). Trichoderma species mediated differential tolerance against biotic stress of phytopathogens in Cicer arietinum L. J. Basic Microbiol, 55:195-206.

[28] Shanmugam, V., Sharma, V., Ananthapad-manaban. 2008. Genetic relatedness of Trichoderma isolates antagonistic against Fusarium oxysporum f.sp. dianthi inflicting carnation wilt. Folia Microbiologica, 53(2):130-138.

[29] Shentu, X., Zhan, X., Ma, Z., Yu, X. and Zhang, C. 2014. Antifungal activity of metabolites of the endophytic fungus Trichoderma brevicompactum from garlic. Brazilian Journal of Microbiology, 45(1):248-254.

[30] Shiau, F.L., Chung, W.C., Huang, J.W. and Huang, H.C. 1999. Organic amendment of commercial culture media for improving control of Rhizoctonia damping off of cabbage. Can. J. Plant Pathol., 21:368-374

[31] Sivan, A. and Chet, I. 1989. Degradation of fungal cell walls by lytic enzymes of Trichoderma harzianum. Journal of General Microbiology, 135:675-682.

[32] Sundar, A.R., Das, N.D. and Krishnaveni, D. 1995. In vitro antgonism of Trichoderma spp. against two fungal pathogens of castor. Indian Journal of Plant Protection, 23(2):152-155.

[33] Tran, N.H. 2010.using Trichoderma species for biological control of plant pathogens in Vietnam. J. ISSAAS, 16(1):17-21.

[34] Tuite, J. 1969. Plant Pathological Methods: Fungi and Bacteria Burgess Pub. Co. Minneapolis, Minn., USA. P. 293.

[35] Vinale, F., Ghisalberti, E.L., Sivasithamparam, K. et al. 2009. Factors affecting the production of Trichoderma harzianum secondary metabolites during the interaction with different plant pathogens. Let Appl Microbiol, 48: 705-11. 

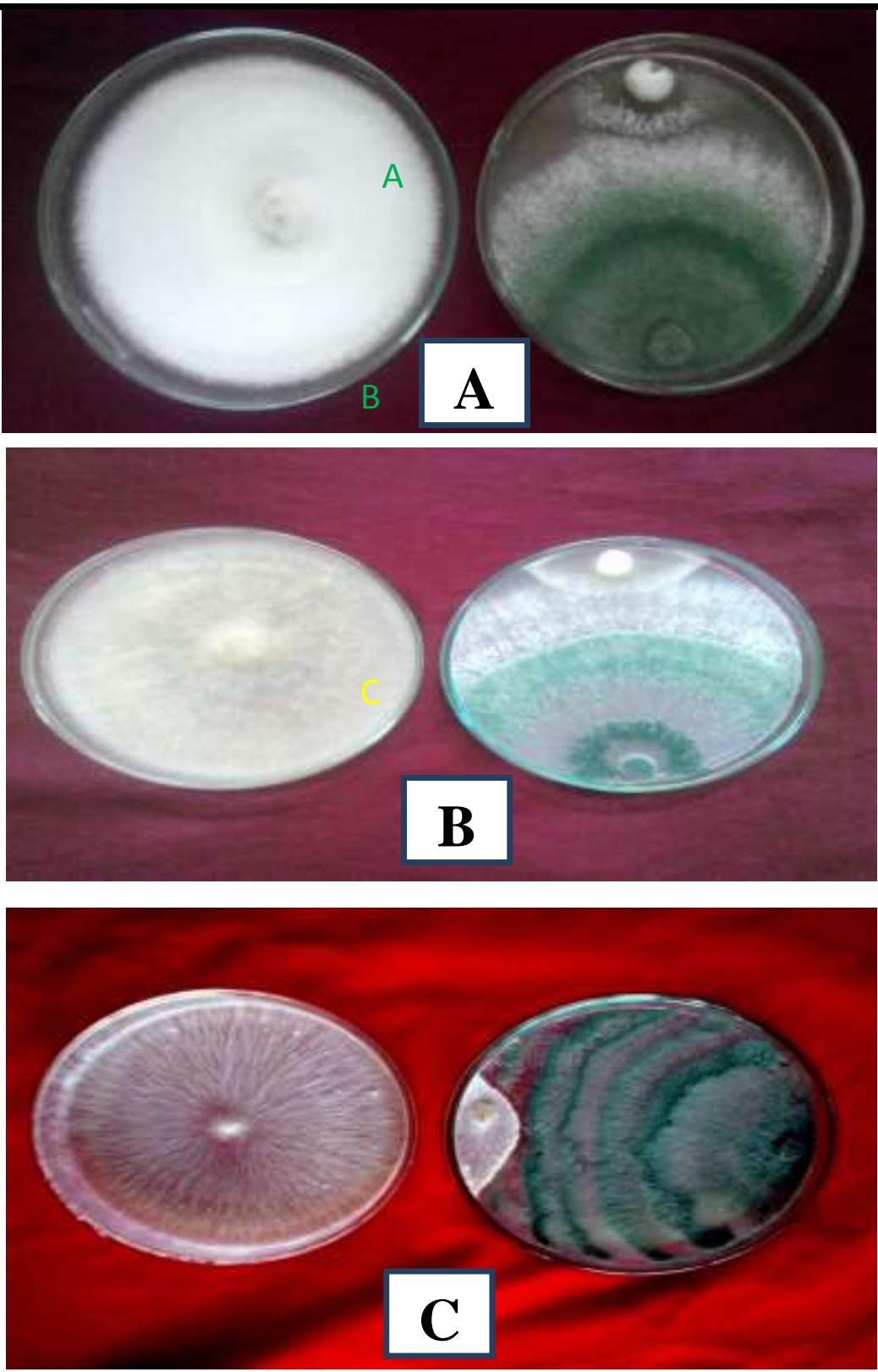

Fig. 1: Antagonism of T. harzianum isolate Co-7 in dual culture PDA plate against A. Trichoderma and Fusarium oxysporum, B. Trichoderma and Rhizoctonia solani, C. Trichoderma and Sclerotium rolfsii [right]; and control plates [left] along with dual culture.

Table 1. Screening of Trichodermaharzianum isolates against Fusarium oxysporum, Rhizoctonia solani and Sclerotium rolfsii by dual culture technique on PDA plates.

\begin{tabular}{|c|c|c|c|}
\hline \multirow{2}{*}{$\begin{array}{c}\text { Isolates of } T . \\
\text { harzianum }\end{array}$} & \multicolumn{3}{|c|}{ \% inhibition of radial growth over control } \\
\cline { 2 - 4 } & F. oxysporum & R. solani & S. rolfsii \\
\hline Co-1 & 70.00 & 67.7 & 77.7 \\
\hline Co-2 & 61.1 & 66.6 & 73.3 \\
\hline Co-3 & 71.1 & 64.4 & 68.8 \\
\hline Co-4 & 60.0 & 72.2 & 65.5 \\
\hline Co-5 & 76.6 & 73.3 & 77.7 \\
\hline Co-6 & 62.2 & 58.8 & 67.7 \\
\hline Co-7 & 82.2 & 78.8 & 83.3 \\
\hline Co-8 & 72.2 & 74.4 & 63.3 \\
\hline
\end{tabular}




\begin{tabular}{|c|c|c|c|}
\hline Co-9 & 64.4 & 62.2 & 66.6 \\
\hline Co-10 & 68.8 & 65.5 & 80.0 \\
\hline Co-11 & 62.2 & 81.1 & 71.1 \\
\hline Co-12 & 78.8 & 77.7 & 75.5 \\
\hline Co-13 & 71.1 & 80 & 67.7 \\
\hline Co-14 & 66.6 & 62.2 & 64.4 \\
\hline Co-15 & 76.6 & 68.8 & 72.2 \\
\hline Co-16 & 66.6 & 70.0 & 78.8 \\
\hline Co-17 & 73.3 & 65.5 & 61.1 \\
\hline Co-18 & 74.4 & 64.4 & 76.6 \\
\hline Co-19 & 72.2 & 63.3 & 66.6 \\
\hline Co-20 & 71.1 & 78.8 & 73.3 \\
\hline
\end{tabular}

Table 2. Effect of Trichoderma fortified compost in controlling seedling mortality of chickpea in open field.

\begin{tabular}{|l|c|c|c|c|}
\hline \multicolumn{1}{|c|}{ Treatments } & \multicolumn{2}{c|}{$\begin{array}{c}\text { \% Reduction } \\
\text { of total } \\
\text { mortality }\end{array}$} \\
\cline { 2 - 5 } & Pre-emergence & Post-emergence & Total & - \\
\hline $\mathrm{T} 1=$ Untreated control & $10.5 \mathrm{a}$ & $27.4 \mathrm{a}$ & $37.8 \mathrm{a}$ & $18.7 \mathrm{~b}$ \\
\hline $\begin{array}{l}\mathrm{T}_{2}=\text { Wheat bran Colonized Trichoderma } \text { without } \\
\text { compost }\end{array}$ & $5.5 \mathrm{~b}$ & $13.2 \mathrm{~b}$ & 50.52 \\
\hline $\mathrm{T}_{3}=$ Colonized Trichoderma with saw dust & $5.2 \mathrm{bc}$ & $12.0 \mathrm{~b}$ & $17.3 \mathrm{~b}$ & 54.23 \\
\hline $\mathrm{T}_{4}=$ Colonized Trichoderma with cow dung & $4.1 \mathrm{~d}$ & $8.9 \mathrm{~d}$ & $13.0 \mathrm{~d}$ & 65.6 \\
\hline $\mathrm{T}_{5}=$ Colonized Trichoderma with tea waste & $4.5 \mathrm{bc}$ & $9.1 \mathrm{~cd}$ & $13.6 \mathrm{~cd}$ & 64.02 \\
\hline $\mathrm{T}_{6}=$ Colonized Trichoderma with water hyacinth & $5.0 \mathrm{bc}$ & $11.6 \mathrm{bc}$ & $16.1 \mathrm{bc}$ & 57.4 \\
\hline $\mathrm{T}_{7}=$ Colonized Trichoderma with poultry manure & $3.2 \mathrm{~d}$ & $8.4 \mathrm{~d}$ & $11.6 \mathrm{~d}$ & 69.31 \\
\hline
\end{tabular}

*Means in a column followed by the same letters does not differ significantly $(p=0.05)$ according to DMRT test.

Table 3. Effect of Trichoderma fortified compost on incidence of chickpea diseases in the field.

\begin{tabular}{|c|c|c|c|c|c|c|}
\hline \multirow{2}{*}{ Treatments } & \multicolumn{2}{|c|}{$\begin{array}{l}\text { Fusarium wilt } \\
\text { ( F. oxysporum) }\end{array}$} & \multicolumn{2}{|c|}{$\begin{array}{l}\text { Collar rot } \\
\text { ( S. rolfsii) }\end{array}$} & \multicolumn{2}{|c|}{$\begin{array}{l}\text { Wet root rot } \\
(R . \text { solani) }\end{array}$} \\
\hline & $\begin{array}{l}\text { Disease } \\
\text { incidence }\end{array}$ & $\begin{array}{l}\% \text { reduction } \\
\text { over control }\end{array}$ & $\begin{array}{l}\text { Disease } \\
\text { incidence }\end{array}$ & $\begin{array}{l}\% \text { reduction } \\
\text { over control }\end{array}$ & $\begin{array}{l}\text { Disease } \\
\text { incidence }\end{array}$ & $\begin{array}{l}\% \text { reduction } \\
\text { over control }\end{array}$ \\
\hline $\mathrm{T} 1=$ Untreated control & $36.4 \mathrm{a}$ & - & $35.9 \mathrm{a}$ & - & $25.7 \mathrm{a}$ & - \\
\hline $\begin{array}{l}\mathrm{T}_{2}=\text { Wheat bran Colonized } \\
\text { Trichodermawithout compost }\end{array}$ & $26.6 \mathrm{~b}$ & 26.9 & $25.2 \mathrm{~b}$ & 29.8 & $20.9 \mathrm{~b}$ & 18.7 \\
\hline $\begin{array}{l}\mathrm{T}_{3}=\text { Colonized Trichoderma } \\
\text { with saw dust }\end{array}$ & $22.7 \mathrm{c}$ & 37.6 & $21.8 \mathrm{c}$ & 39.3 & $16.2 \mathrm{c}$ & 36.9 \\
\hline $\begin{array}{l}\mathrm{T}_{4}=\text { Colonized Trichoderma } \\
\text { with cow dung }\end{array}$ & $17.3 \mathrm{e}$ & 52.5 & $16.8 \mathrm{e}$ & 53.2 & $12.9 \mathrm{e}$ & 49.8 \\
\hline $\begin{array}{l}\mathrm{T}_{5}=\text { Colonized Trichoderma } \\
\text { with tea waste }\end{array}$ & $19.5 \mathrm{de}$ & 46.4 & $19.5 \mathrm{de}$ & 45.7 & 14.6 de & 43.2 \\
\hline $\begin{array}{l}\mathrm{T}_{6}=\text { Colonized Trichoderma } \\
\text { with water hyacinth }\end{array}$ & $22.5 \mathrm{c}$ & 38.2 & $21.4 \mathrm{c}$ & 40.4 & $15.2 \mathrm{~cd}$ & 40.9 \\
\hline $\begin{array}{l}\mathrm{T}_{7}=\text { Colonized Trichoderma } \\
\text { with poultry manure }\end{array}$ & $13.2 \mathrm{f}$ & 63.7 & $12.9 \mathrm{f}$ & 64.1 & $12.5 \mathrm{f}$ & 51.4 \\
\hline
\end{tabular}


Table 4. Effect of Trichoderma fortified compost on severity of chickpea diseases in field.

\begin{tabular}{|c|c|c|c|c|c|c|}
\hline \multirow{2}{*}{ Treatments } & \multicolumn{2}{|c|}{$\begin{array}{l}\text { Fusarium wilt } \\
\text { (F. oxysporum) }\end{array}$} & \multicolumn{2}{|c|}{$\begin{array}{l}\text { Collar rot } \\
\text { ( S. rolfsii) }\end{array}$} & \multicolumn{2}{|c|}{$\begin{array}{l}\text { Wet root rot } \\
(\text { R. solani })\end{array}$} \\
\hline & PDI & $\begin{array}{l}\% \text { reduction } \\
\text { over control }\end{array}$ & PDI & $\begin{array}{l}\% \text { reduction } \\
\text { over control }\end{array}$ & PDI & $\begin{array}{l}\% \text { reduction } \\
\text { over control }\end{array}$ \\
\hline $\mathrm{T}_{1}=$ Untreated control & $38.5 \mathrm{a}$ & - & $32.3 \mathrm{a}$ & - & $36.4 \mathrm{a}$ & - \\
\hline $\begin{array}{l}\mathrm{T}_{2}=\text { Wheat bran Colonized } \\
\text { Trichodermawithout compost }\end{array}$ & $30.3 \mathrm{~b}$ & 21.3 & $28.1 \mathrm{~b}$ & 13.0 & $27.1 \mathrm{~b}$ & 25.5 \\
\hline $\begin{array}{l}\mathrm{T}_{3}=\text { Colonized Trichoderma } \text { with } \\
\text { saw dust }\end{array}$ & $25.0 \mathrm{c}$ & 35.1 & $22.9 \mathrm{c}$ & 29.1 & $23.9 \mathrm{~b}$ & 34.3 \\
\hline $\begin{array}{l}\mathrm{T}_{4}=\text { Colonized Trichoderma with } \\
\text { cow dung }\end{array}$ & $15.7 \mathrm{ef}$ & 59.2 & $12.5 \mathrm{de}$ & 61.3 & $14.6 \mathrm{c}$ & 59.9 \\
\hline $\begin{array}{l}\mathrm{T}_{5}=\text { Colonized Trichoderma } \text { with tea } \\
\text { waste }\end{array}$ & $18.8 \mathrm{de}$ & 51.2 & $15.7 \mathrm{~d}$ & 51.4 & $16.7 \mathrm{c}$ & 54.1 \\
\hline $\begin{array}{l}\mathrm{T}_{6}=\text { Colonized Trichoderma } \text { with } \\
\text { water hyacinth }\end{array}$ & $22.9 \mathrm{~cd}$ & 40.5 & $20.8 \mathrm{c}$ & 35.6 & $22.9 \mathrm{~b}$ & 37.1 \\
\hline $\begin{array}{l}\mathrm{T}_{7}=\text { Colonized Trichoderma with } \\
\text { poultry manure }\end{array}$ & $13.5 \mathrm{f}$ & 64.9 & $10.4 \mathrm{e}$ & 67.8 & $12.5 \mathrm{c}$ & 65.7 \\
\hline
\end{tabular}

Means within same column followed by common letter(s) are not significantly different $(P=0.05)$ by DMRT.

Table 5. Effect of Trichoderma fortified compost on growth promoting and yield components of chickpea

\begin{tabular}{|l|c|c|c|c|c|}
\hline \multicolumn{1}{|c|}{ Treatments } & $\begin{array}{c}\text { No. of branch } \\
\text { plant }\end{array}$ & $\begin{array}{c}\text { No. of pods } \\
\text { plant }^{-1}\end{array}$ & $\begin{array}{c}\text { Plant height } \\
(\mathrm{cm})\end{array}$ & $\begin{array}{c}1000 \text { seed wt. } \\
(\mathrm{g})\end{array}$ & $\begin{array}{c}\text { Seed yield (t } \\
\left.\text { ha }^{-1}\right)\end{array}$ \\
\hline $\mathrm{T}_{1}=$ Untreated control & $3.0 \mathrm{e}$ & $32.8 \mathrm{c}$ & $42.1 \mathrm{~d}$ & $140.2 \mathrm{~d}$ & $1.02 \mathrm{f}$ \\
\hline $\begin{array}{l}\mathrm{T}_{2}=\text { Wheat bran Colonized } \\
\text { Trichoderma } \text { without compost }\end{array}$ & $3.2 \mathrm{de}$ & $35.5 \mathrm{c}$ & $46.1 \mathrm{c}$ & $140.9 \mathrm{c}$ & $1.13 \mathrm{e}$ \\
\hline $\begin{array}{l}\mathrm{T}_{3}=\text { Colonized Trichoderma } \text { with } \\
\text { saw dust }\end{array}$ & $3.5 \mathrm{~cd}$ & $37.0 \mathrm{c}$ & $47.1 \mathrm{c}$ & $150.1 \mathrm{c}$ & $1.19 \mathrm{de}$ \\
\hline $\begin{array}{l}\mathrm{T}_{4}=\text { Colonized Trichoderma } \text { with } \\
\text { cow dung }\end{array}$ & $4.2 \mathrm{ab}$ & $43.0 \mathrm{ab}$ & $52.1 \mathrm{a}$ & $160.5 \mathrm{a}$ & $1.42 \mathrm{~b}$ \\
\hline $\begin{array}{l}\mathrm{T}_{5}=\text { Colonized Trichoderma } \text { with tea } \\
\text { waste }\end{array}$ & $4.1 \mathrm{~b}$ & $38.0 \mathrm{bc}$ & $51.5 \mathrm{ab}$ & $150.7 \mathrm{~b}$ & $1.30 \mathrm{c}$ \\
\hline $\begin{array}{l}\mathrm{T}_{6}=\text { Colonized Trichoderma } \text { with } \\
\text { water hyacinth }\end{array}$ & $3.6 \mathrm{c}$ & $37.2 \mathrm{bc}$ & $47.5 \mathrm{bc}$ & $150.3 \mathrm{bc}$ & $1.27 \mathrm{~cd}$ \\
\hline $\begin{array}{l}\mathrm{T}_{7}=\text { Colonized Trichoderma } \text { with } \\
\text { poultry manure }\end{array}$ & $4.5 \mathrm{a}$ & $46.8 \mathrm{a}$ & $55.2 \mathrm{a}$ & $160.9 \mathrm{a}$ & $1.54 \mathrm{a}$ \\
\hline
\end{tabular}
Means within same column followed by common letter(s) are not significantly different $(P=0.05)$ by DMRT. 